\title{
Combined targeting of TGF- $\beta 1$ and integrin $\beta 3$ impairs lymph node metastasis in a mouse model of non-small-cell lung cancer
}

\author{
Elizabeth Salvo ${ }^{1}$, Saray Garasa', Javier Dotor ${ }^{2}$, Xabier Morales ${ }^{1}$, Rafael Peláez ${ }^{1}$, Peter Altevogt ${ }^{3}$ and Ana Rouzaut ${ }^{1,4^{*}}$
}

\begin{abstract}
Background: Transforming Growth Factor beta (TGF- $\beta$ ) acts as a tumor suppressor early in carcinogenesis but turns into tumor promoter in later disease stages. In fact, TGF- $\beta$ is a known inducer of integrin expression by tumor cells which contributes to cancer metastatic spread and TGF- $\beta$ inhibition has been shown to attenuate metastasis in mouse models. However, carcinoma cells often become refractory to TGF- $\beta$-mediated growth inhibition. Therefore identifying patients that may benefit from anti-TGF- $\beta$ therapy requires careful selection.

Methods: We performed in vitro analysis of the effects of exposure to TGF- $\beta$ in NSCLC cell chemotaxis and adhesion to lymphatic endothelial cells. We also studied in an orthotopic model of NSCLC the incidence of metastases to the lymph nodes after inhibition of TGF- $\beta$ signaling, $\beta 3$ integrin expression or both.

Results: We offer evidences of increased $\beta 3$-integrin dependent NSCLC adhesion to lymphatic endothelium after TGF- $\beta$ exposure. In vivo experiments show that targeting of TGF- $\beta$ and $\beta 3$ integrin significantly reduces the incidence of lymph node metastasis. Even more, blockade of $\beta 3$ integrin expression in tumors that did not respond to TGF- $\beta$ inhibition severely impaired the ability of the tumor to metastasize towards the lymph nodes.

Conclusion: These findings suggest that lung cancer tumors refractory to TGF- $\beta$ monotherapy can be effectively treated using dual therapy that combines the inhibition of tumor cell adhesion to lymphatic vessels with stromal TGF- $\beta$ inhibition.
\end{abstract}

Keywords: Integrin, TGF- $\beta$, Metastases, Lymph nodes, Lymphatic vessels

\section{Background}

Lung cancer is a highly prevalent disease and is one of the leading causes of death worldwide. This neoplasia is usually detected in advanced stages and it has a 5-year survival rate of $20 \%$ [1]. Lung adenocarcinoma (AC) and lung squamous cell carcinoma (SCC) are the most common histological subtypes of lung cancer and they are generally smokingrelated [2]. Tobacco contributes to the onset of lung carcinoma by inducing the expression of several cytokines including the molecule TGF- $\beta$, which is secreted by stromal fibroblasts [3]. TGF- $\beta$ is a ubiquitous and pleiotropic cytokine that plays a dual role in cancer development. While it acts as a tumor suppressor in the early

\footnotetext{
* Correspondence: arouzaut@unav.es

'Oncology, CIMA, 31008 Pamplona, Spain

${ }^{4}$ Department of Biochemistry and Genetics, University of Navarra, 31080 Pamplona, Spain

Full list of author information is available at the end of the article
}

stages of the disease, at later stages of tumor development it contributes to malignant transformation through the activation of cell proliferation, metastasis and tumor angiogenesis $[4,5]$. Indeed, the production of TGF- $\beta$ by tumor and stromal cells in response to radiotherapy and chemotherapy contributes to treatment resistance [6], and TGF- $\beta$ inhibition in these cases improves treatment responses, particularly in models of solid carcinomas such as breast cancer [7].

The presence of lymph node metastasis is strongly associated with low survival rates in cancer patients $[8,9]$, even in those diagnosed at early stages of the disease [10]. Tumor metastasis largely depends on the interaction between cancer cells and the tumor stroma. While host cells have tumor-suppressing capacities, malignancy induces several changes in the stroma (e.g., tumor hypoxia) that eventually promote cell proliferation, invasion and metastasis [11]. 
Significantly, cytokines such as TGF- $\beta$ play a key role in the transformation of the stroma during tumor development. Moreover, we have shown previously that TGF- $\beta$-induced factors are associated with worse overall prognosis in nonsmall-cell lung cancer (NSCLC) patients [12].

The lymphatic vessels constitute the main route by which solid carcinomas access the lymph nodes. Several studies have demonstrated that lymphangiogenesis is positively correlated with lymph node spread and adverse NSCLC prognoses [9]. Furthermore, both tumor and immune cells have been captured by electron microscopy in transit through channels formed in lymphatic endothelial cell (LEC) monolayers [13], although the molecular mechanisms by which tumor and immune cells enter lymphatic capillaries remain unknown. Lymphatic metastasis of NSCLCs may be facilitated by the specific morphological characteristics of the lymphatic endothelium. These vessels present an interrupted basal membrane [14] and their inter-endothelial junctional complexes are distributed in a dispersed button-like disposition [15]. Therefore, as it has been described for leucocytes, cell transit across these specific capillaries appears to be indolent [16]. Nevertheless, inflammation induces changes in the phenotype of the initial lymphatic vasculature [17] that elicit integrin-dependent mechanisms for an efficient recruitment of inflammatory cells $[18,19]$.

As cancer is considered an inflammatory disease [20], it is important to determine whether integrins and their receptors also participate in tumor cell intravasation into the lymphatic vasculature. In fact, several studies have proposed an association between increased integrin expression in tumors and enhanced metastasis to the lymph nodes $[21,22]$, and we previously demonstrated that hypoxia and nicotine promote the chemotaxis and adhesion of lung carcinoma cells to lymphatic endothelial cells $[23,24]$. In the present study, we examined the relationship between TGF- $\beta$ exposure and tumor cell metastasis to the lymph nodes, and we sought to determine whether this relationship is mediated by integrin-dependent mechanisms.

\section{Materials and methods}

\section{Cell culture and treatments}

The human NSCLC cell lines H157, A549 and H1299, as well as cryopreserved primary Lung-Derived Human Lymphatic Microvascular Endothelial Cells (HMVEC-LLy, Lonza (Walkersville, MD, USA), were grown as described previously [12]. The cell lines were authenticated by PCR amplification of genomic DNA using specific primers for the specific CDKN2A mutation (c.205 G > T, in exon 2) and a KRAS mutation (c.34 G $>\mathrm{C}$, in exon 2), and they were identified by the subsequent sequencing of the PCR products.

NSCLC cells were cultured in serum-free RPMI with $2 \mathrm{ng} / \mathrm{ml}$ human recombinant TGF- $\beta$ (R\&D Systems,
Minneapolis, USA) for $24 \mathrm{~h}$ or 5 days. The medium was replaced and fresh cytokine was added every $48 \mathrm{~h}$. For TGF- $\beta$ blocking experiments, tumor cells were incubated with $10 \mathrm{mM}$ of the TGF- $\beta$ RI chemical inhibitor, SB431542 hydrate (Sigma-Aldrich, Steinheim, Germany), or $200 \mu \mathrm{g} / \mathrm{ml}$ of the TGF- $\beta$ inhibitory peptide P144 (Polypetide Group, Strasbourg, France), $30 \mathrm{~min}$ before TGF- $\beta$ treatment. Integrin $\alpha v \beta 3$ blockade in $\mathrm{H} 157$ cells was achieved by adding $10 \mu \mathrm{g} / \mathrm{ml}$ of $\alpha \mathrm{v} \beta 3$-blocking antibody (MAB1976Z, Millipore, Billerica, MA, USA) 30 min before performing the assay. FAK was inhibited by incubation overnight with $1 \mu \mathrm{M}$ PF-573228 (Sigma-Aldrich, Steinheim, Germany).

\section{Cell adhesion assays}

Analysis of H157 cell adhesion to the lymphatic endothelium was performed as described previously [24]. Briefly, $3 \times 10^{4} \mathrm{H} 157$ cells were labeled for $20 \mathrm{~min}$ at $37^{\circ} \mathrm{C}$ with $10 \mu \mathrm{M}$ calcein-AM (Sigma-Fluka, Steinheim, Germany), seeded on LEC monolayers and allowed to attach for $30 \mathrm{~min}$ at $37^{\circ} \mathrm{C}$. Non-adherent cells were washed out and cell fluorescence was measured on a BMG Polar star Galaxy plate reader (Lab Technologies, Barcelona, Spain), using an excitation wavelength of $485 \mathrm{~nm}$ and a $520 \mathrm{~nm}$ emission filter.

\section{Cell transmigration assays}

A total of $4 \times 10^{4}$ LECs were seeded on $8 \mu \mathrm{m}$ pore-size filters in modified Boyden chambers (BD Biosciences, San José, CA, USA) as described previously [19]. Next, $7 \times 10^{4} \mathrm{H} 157$ cells in $150 \mu \mathrm{l}$ of serum-free RPMI medium were added and allowed to migrate for $24 \mathrm{~h}$ at $37^{\circ} \mathrm{C}$ towards the complete media added to the lower side of the filters. Transmigration efficiency was calculated as described previously [19].

The L1CAM and CD31 integrin receptors were blocked by pre-incubation of tumor cells or endothelial cells with blocking antibodies $(20 \mu \mathrm{g} / \mathrm{ml})$ for $1 \mathrm{~h}$ before carrying out the transmigration assays. The antibodies against human L1CAM (L1-9.3, directed against the L1CAM homotypic binding region, and L1-35.9, directed against the L1CAM RGD binding region) have been described previously [25]. The CD31 antibody was purchased from Sigma Aldrich (Steinheim, Germany).

\section{RNA isolation and PCR array}

Total RNA was extracted with Trizol (Gibco, Carlsbad, CA, USA) according to the manufacturer's instructions. For the PCR array, cDNA synthesis was carried out using $1 \mu \mathrm{g}$ of total RNA and the $\mathrm{RT}^{2}$ First Strand Kit (SABiosciences, Qiagen Dusseldorf, Germany). Gene expression was profiled using the ECM and Adhesion Molecules RT $^{2}$ Profiler $^{\mathrm{TM}}$ PCR Array (SABiosciences, Qiagen 
Dusseldorf, Germany), according to the manufacturer's instructions.

\section{Tumor cell transfection}

H157 cells $\left(1 \times 10^{6}\right.$ cells $\left./ \mathrm{ml}\right)$ were transfected with $20 \mu \mathrm{g}$ of a scrambled RNA or a $\mathrm{HuSH}^{\mathrm{TM}}$ shRNA Plasmid Panels-29mer targeting integrin $\beta 3$ (Origene, Rockville, MD, USA) in Opti-MEM medium (Invitrogen, Barcelona, Spain) using a Biorad Gene Pulsar I electroporator (Biorad, Berkeley, USA). Stable $\beta 3$ integrin-silenced clones or cells expressing a non-specific scrambled RNA sequence were selected by culturing cells in the presence of $1.5 \mu \mathrm{g} / \mathrm{ml}$ puromycin-dihydrochloride antibiotic (Sigma-Aldrich, Steinheim, Germany). To generate GFP-expressing cells, H157 cells $\left(2 \times 10^{5}\right)$ were transfected with $1 \mu \mathrm{g}$ of the pEGFP-C1 plasmid (Clontech, Mountain-View, CA, USA) using FuGENE 6 Transfection Reagent (Roche, Barcelona, Spain), following the manufacturer's instructions. Transfection efficiency was confirmed by flow cytometry and fluorescent microscopy, respectively.

\section{Western blot}

Total cell protein extracts were prepared using RIPA buffer as described previously [12]. Membranes were blocked for $1 \mathrm{~h}$ with $10 \%$ non-fat milk or 5\% BSA in TBS containing $0.1 \%$ Tween-20, and then incubated overnight at $4{ }^{\circ} \mathrm{C}$ with the primary antibody at the dilutions recommended by the manufacturer.

The primary antibodies against FAK and phospho-FAK (Tyr397) were purchased from Cell Signaling (Danvers, MA, USA), and the anti- $\beta$-actin from Sigma-Aldrich (Steinheim, Germany). HRP-conjugated anti-rabbit IgG (Santa Cruz Biotechnology, Santa Cruz, CA, USA) was used as the secondary antibody. Blots were developed using Lumi-Light Plus Reagent (Roche, Barcelona, Spain), and the autoradiograms were scanned using a GS-800 calibrated densitometer and analyzed using Quantity One software (Biorad, Berkeley, CA,USA).

\section{Orthotopic mouse model of NSCLC}

All protocols involving animal experiments were approved by the Experimentation Ethics Committee of the University of Navarra. Female athymic nude mice (5-6 weeks old) were purchased from Harlan Laboratories and GFP-H157 cells $\left(1 \times 10^{6}\right)$ in PBS containing $10 \mu \mathrm{g}$ of Matrigel (BD Biosciences, San José, CA, USA) were injected in a total volume of $20 \mu \mathrm{l}$ into the left lung of these nude mice as described previously [26]. Each mouse was then injected intra-peritoneally with either vehicle (PBS) or $200 \mu \mathrm{g}$ of the TGF- $\beta$ inhibitor peptide P144 daily. Mice were sacrificed 28 days after treatment or upon exhibiting symptoms of cachexia. Primary tumors and brachial and axillary lymph nodes from both sides were extracted, fixed in Bouin solution and paraffin-embedded for histopathological analysis.

Immunohistochemistry and confocal microscopy imaging Endogenous peroxidase activity was quenched in formalinfixed paraffin-embedded tissue sections ( $3 \mu \mathrm{m}$ thick) and they were then exposed to microwaves. Non-specific binding was blocked by incubation for $30 \mathrm{~min}$ in $5 \%$ goat serum in TBS, before the sections were incubated overnight at $4^{\circ} \mathrm{C}$ with antibodies against GFP (1:1000, Abcam, Cambridge, UK) or $\beta 3$ integrin (1:1000, Chemicon/ Millipore, Billerica, MA, USA). The sections were then incubated for $30 \mathrm{~min}$ at room temperature with Envision polymer (Dako) to increase the signal intensity. Peroxidase activity was visualized with diaminobenzidine, and the sections were counterstained with hematoxylin and mounted in DPX mounting medium (BDH Chemical, Poole, UK). GFP staining was scored qualitatively and expressed as the proportion of positive cells $(0-100 \%)$, as described previously [12].

Cells were seeded onto $35 \mathrm{~mm}$ glass-bottom culture dishes (MatTek Corporation, Ashland, MA, USA) for confocal microscopy (Ultraview ERS, PerkinElmer, Waltman, MA, USA) and the images from stacks ( $0.5 \mu \mathrm{m}$ deep) were captured every 2 min over 2 h using a $63 \times$ water objective, and they were analyzed using Ultraview ERS (PerkinElmer, Waltman, MA, USA) and FIJI (Image J, Bethesda, MA, USA) software.

\section{Primary tumor growth analysis}

Tumor growth was quantified using FIJI software (Image J) on microphotograph images obtained on a Zeiss Axio Imager M1 microscope (Carl Zeiss, AG, Oberkochen, Germany) from fixed samples. The methods and parameters used for micro-CT image acquisition and image reconstruction have been described elsewhere [27].

\section{Statistical analysis}

Normally distributed data were analyzed using a Student's $t$-test or ANOVA followed by post-hoc analyses. Data with a non-parametric distribution were analyzed using the Kruskal-Wallis and Mann-Whitney U-tests. Mouse survival was analyzed using the log-rank test. Differences were considered significant at $\mathrm{p}<0.05$. All analyses were performed using SPSS 15.0 or Graph Pad Prism 5 software.

\section{Results}

TGF- $\beta$ exposure enhances H157 NSCLC cell adhesion and transmigration across lymphatic endothelial cell monolayers

To establish an in vitro system in which to study our hypothesis we first evaluated the response of three NSCLC cell lines (H1299, H157 and A549) to TGF- $\beta$ by measuring 
SMAD2 phosphorylation and its inhibition by cell exposition to the specific inhibitor of the TGF- $\beta$ receptor Type I kinase SB431542, or to P144, a TGF- $\beta$-binding inhibitory peptide obtained from the sequence of the human TGF- $\beta$ receptor type III (beta-glycan). We observed that although both inhibitors specifically diminished phospho-SMAD signal, P144 inhibited SMAD2 phosphorylation to a lower extent (Additional file 1: Figure S1A). In our view, SB431552 inhibits more intensely SMAD2 phosphorylation because it specifically targets TGF- $\beta$ RI kinase and therefore the subsequent phosphorylation of SMAD, while P144 is a short peptide derived from the sequence of the TGF- $\beta$ RIII (beta-glycan) that binds to soluble TGF- $\beta$ and blocks TGF$\beta$ signaling through all its possible receptors. To study the effect of TGF- $\beta$ on cell dynamics we performed cell migration assays to analyze cell movements towards chemotactic factors. Cell migration was enhanced in NSCLC cells exposed to TGF- $\beta$ (Additional file 1: Figure S1B and C). Based on these findings, we selected the H157 NSCLC cell line with which to model the TGF- $\beta$ response of lung cancer cells.

To determine whether TGF- $\beta$ enhances NSCLC cell migration through lymphatic vessels, we studied H157 cell adhesion and transmigration across monolayers of primary human LECs. TGF- $\beta$ treatment increased cell adherence to LEC monolayers and altered cell motility when measured by video microscopy (Figure 1A and B). Indeed, while only $30 \%$ of untreated cells moved on the endothelial surface (by blebbing), in the presence of TGF- $\beta$ the number of motile cells multiply three fold and moved by emitting filopodia, indicative of integrinmediated displacement [28] (Figure $1 \mathrm{~B}$ and $\mathrm{C}$ ). We also tested whether TGF- $\beta$ treated cells traversed LEC monolayers at greater intensity in Boyden chambers assays. Results show that it was the case: cell transmigration across endothelial layers was increased more than twofold in TGF- $\beta$-treated cells (Figure 1D). As expected, this increment was abrogated when cells were incubated with the TGF- $\beta$ RI inhibitor SB431542, indicating that this effect is specific to the cytokine.

\section{Integrin mRNA expression is increased in TGF- $\beta$-treated cells}

To obtain a metastases-related mRNA signature specific to TGF- $\beta$-treated H157 NSCLC cells, we used the SABiosciences $\mathrm{RT}^{2}$ Profiler $^{\mathrm{Tm}}$ PCR Array that measures the expression of 94 genes related to adhesion molecules, proteases and extracellular matrix components. Interestingly enough, TGF- $\beta$ induced increases in the expression of several integrins, such as $\alpha 2, \alpha v, \beta 1$ integrins and most prominently, $\beta 3$ integrin (Figure 2A) as it has been described in other systems [29]. Besides, major changes in the expression of genes encoding extracellular matrix proteins were observed, including collagens type I,
VII and XIV, fibronectin and laminin (Additional file 2: Figure S2). We also observed increased expression of MMPs, ADAMTS, TIMP and CTGF, among other genes. To control for the specificity of TGF- $\beta$ induction we hybridized the arrays with samples treated with SB 431542 or with P144, a peptide inhibitor of TGF- $\beta$ developed inhouse [30]. Accordingly, the differential expression of 18 selected genes was confirmed by Real-Time PCR, including all the integrins detected (Additional file 2: Figure S2). Of interest, we observed that although the majority of the genes (26/31) responded to both inhibitors in the same sense (diminishing or incrementing gene expression), some differences in the intensities of the responses were detected. These variances can be due to their diverse targeting molecules: while P144 binds to TGF- $\beta$, SB431542 specifically inhibits the phosphorylation of one of its receptors namely TGF- $\beta$ RI. In this sense, five genes presented completely opposite responses depending on the inhibitor used: MMP-10, MMP14, SPARC were induced after treatment with P144 and inhibited by SB431542. These results suggest the existence of TGF- $\beta$-dependent but TGF- $\beta$ RIindependent inhibitory mechanisms involved in the regulation of their transcription. On the contrary E-Selectin and MMP3 expression was induced after treatment with SB431542 and inhibited as a result of P144 exposure. Thus, since SB431542 targets only one of the possible TGF- $\beta$-induced signaling pathways and P144 blights all the different pathways activated by this cytokine, we selected P144 for our experiments in order to target stromal TGF- $\beta$ and inhibit all its effects at once.

\section{$\beta 3$ integrin is required to mediate the TGF- $\beta$ driven increases in cell transmigration across LECs}

Based on the significant induction of integrin expression observed in our experimental conditions, we investigated the role of integrins in NSCLC adhesion to LECs. Exposure to TGF- $\beta$ induced the phosphorylation of the focal adhesion kinase (FAK) in H157 cells, a kinase that mediates integrin activation in response to TGF- $\beta$ treatment (Figure 2B). To confirm the participation of the integrin signaling pathway in cell adhesion to LEC monolayers, we performed adhesion experiments with H157 cells pretreated with PF-573228, a chemical inhibitor of FAK. After FAK inhibition, the number of cells that adhered to LECs decreased to levels observed in untreated cells (Figure 2C). Curiously, PF-573228 did not reduce tumor adhesion to LEC monolayers in control cells. These findings indicate that FAK activation occurs exclusively after exposure of H157 NSCLC cells to TGF- $\beta$ and that it mediates cell adhesion to LEC monolayers.

To specifically demonstrate the participation of these pathways in tumor cell transmigration across LEC monolayers, we performed transmigration assays using cells treated with the TGF $\beta$-RI kinase inhibitor SB431542, the 


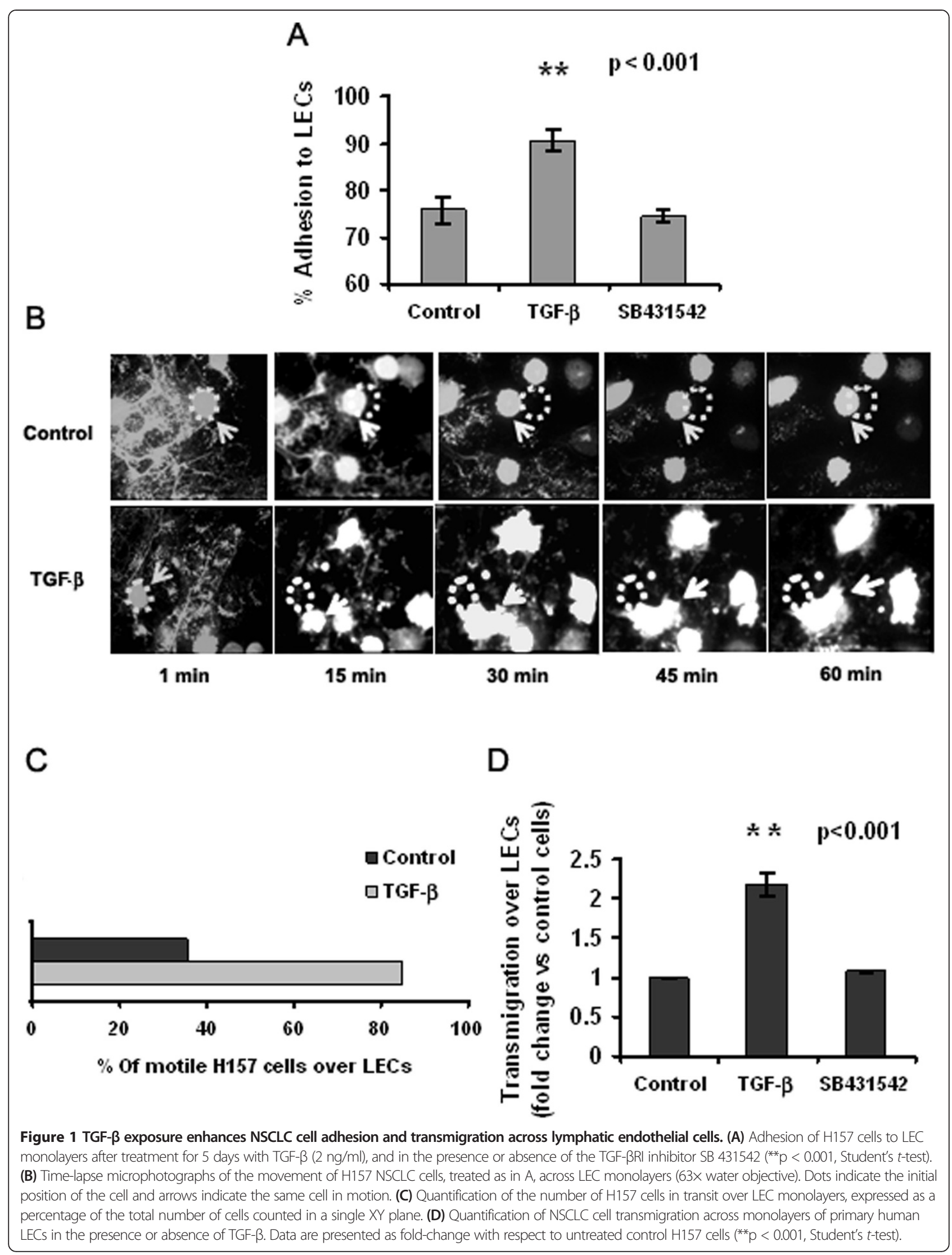




\section{A}

Fold change vs control cells

\begin{tabular}{|c|c|c|c|}
\hline INTEGRINS & TGF- $\beta$ & TGF- $\beta$ + SB431542 & TGF- $\beta$ + P144 \\
\hline ITG $\alpha$ V & 2,0857 & $-1,4336$ & $-1,0307$ \\
\hline ITG $\alpha 2$ & 2,2842 & 1,3891 & $-1,2726$ \\
\hline ITG $\beta 5$ & 2,6145 & 1,0829 & 1,7645 \\
\hline ITG $\beta 1$ & 2,8672 & 1,1162 & $-1,0378$ \\
\hline ITG $\beta 3$ & 10,8548 & 1,6805 & 2.6157 \\
\hline
\end{tabular}

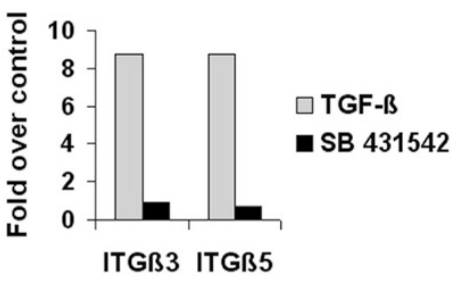

B

C
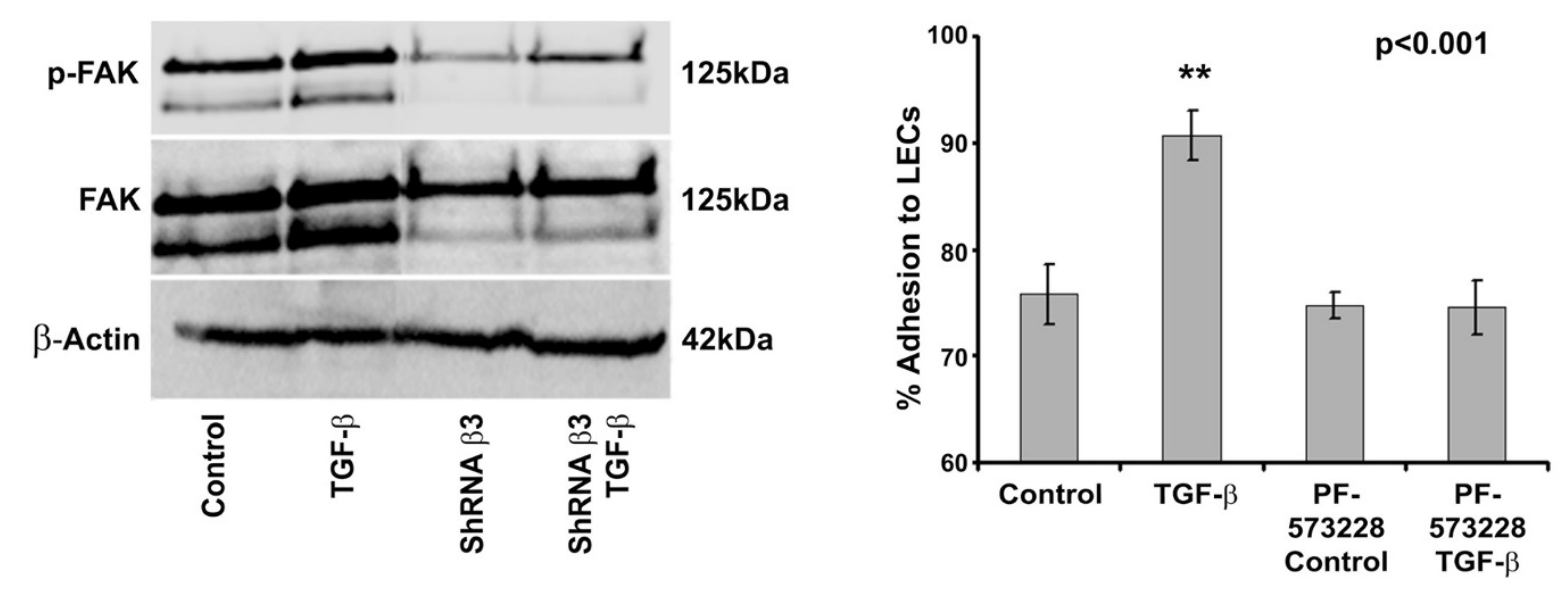

D

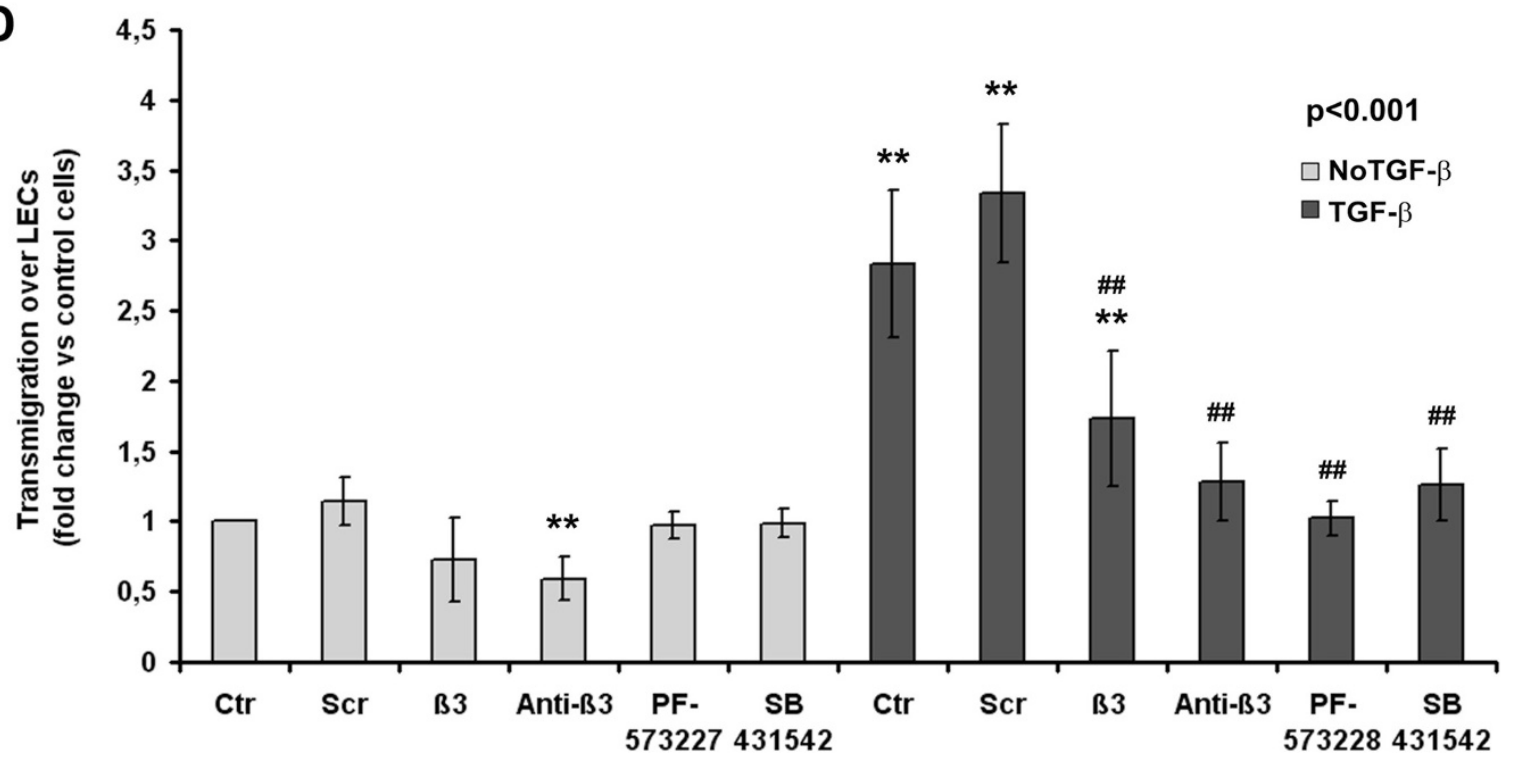

Figure 2 (See legend on next page.) 
(See figure on previous page.)

Figure 2 TGF- $\beta$ treatment induces integrin expression, FAK phosphorylation, $\beta 3$ integrin-dependent adhesion and transmigration of H157 NSCLC cells across LEC monolayers. (A) mRNA expression of several integrins in H157 cells following treatment with TGF- $\beta$ and its inhibitors (fold-change with respect to untreated cells) and confirmation by real-time PCR of the differential expression of $\beta 3$ and $\beta 5$ integrins after exposure to TGF- $\beta$. (B) FAK phosphorylation after TGF- $\beta$ treatment of $\beta 3$ integrin-deficient (shRNA 33 ) and $\beta 3$ integrin-competent H157 NSCLC cells. (C) Adhesion of TGF- $\beta$-treated H157 cells to LEC monolayers in the presence or absence of the FAK inhibitor, PF-573228 $\left(^{* *} \mathrm{p}<0.001\right.$, Student's $t$-test). (D) Quantification of $\mathrm{H} 157$ cell transmigration across LEC monolayers in the presence of the TGF- $\beta$ RI inhibitor SB431542, the FAK inhibitor PF-573228, a blocking $\mathrm{mAb}$ against $\beta 3$ integrin (Anti- $\beta 3$ ) and that of $\beta 3$ integrin-deficient $\mathrm{H} 157$ clones ( $\beta 3$ ). Samples were pretreated with or without TGF- $\beta$ as described in the Materials and methods $\left({ }^{* *} p<0,001\right.$ compared against non-treated cells, ${ }^{\# \#} p<0,001$ compared against TGF $\beta$-treated cells, Mann-Whitney U-test).

FAK inhibitor PF-573228, or after the cells had been pretreated with a blocking antibody against the $\beta 3$ integrin. We also developed H157 clones that were stably transfected to express $\beta 3$ integrin-specific shRNAs. As it is demonstrated in Figure 2D, inhibition of FAK or TGF- $\beta$ signaling and of $\beta 3$ integrin expression or functionality severely impairs the transmigration of TGF- $\beta$ treated H157 cells. Importantly, these effects were not detected or were significantly smaller (e.g. treatment with $\beta 3$ integrin blocking antibodies) in control cells. Therefore, TGF- $\beta$ pretreatment induces incremented cell transmigration across monolayers of lymphatic endothelial cells in a manner that is dependent on the activation of TGF$\beta R I$ and FAK signaling pathways and on the intervention of $\beta 3$ integrin subunits.

When we analyzed H157 cell dynamics on LEC monolayers by confocal video microscopy, we observed that $\beta 3$ integrin expression was required for cells to move across LEC monolayers, to adopt a fibroblast-like morphology and to extrude filopodia (Figure 3). In fact, we found no differences in the average speed and distance covered between $\beta 3$ integrin-silenced cells pretreated with TGF- $\beta$ and untreated control cells. Together, these findings demonstrate that the TGF- $\beta$-dependent increases in tumor cell adhesion and transmigration across LEC monolayers are mediated by $\beta 3$ integrin expression at the tumor cell surface.

L1CAM and CD31 are $\beta 3$ integrin ligands that are expressed on the surface of LECs (Additional file 3: Figure S3). L1CAM has been implicated in tumor metastasis and therapeutic antibodies that target this molecule block tumor growth in experimental models of ovarian and pancreatic cancer [31,32]. To investigate whether these receptors participate in the transmigration of H157 cells across LEC monolayers, we performed transmigration assays in the presence of blocking antibodies against the L1CAM RGD binding region (L1-35.9 $\mathrm{mAb}$ ), the L1CAM homotypic binding region (L1-9.3 $\mathrm{mAb}$ ) and $\mathrm{CD} 31$. All three blocking antibodies reduced the transmigration of TGF- $\beta$-treated H157 tumor cells across LECs by $50 \%$ with respect to the corresponding controls (Figure 4A). As L1CAM and CD31 can interact via homotypic contacts, we studied the effect of blocking these ligands on $\beta 3$ integrin-dependent cell transmigration across LECs. As such, when we repeated the transmigration experiments with $\beta 3$ integrin-silenced $\mathrm{H} 157$ cells, their adhesion to LECs was only reduced by the anti-L1-9.3 antibody that blocks L1CAM homotypic binding (Figure 4B). Hence, H157 cells appear to bind LEC via L1CAM homotypic and L1CAM/integrin $\beta 3$ and CD31/integrin $\beta 3$ heterotypic binding. Interestingly, when cells were simultaneously incubated with both L1CAM blocking antibodies prior to performing the adhesion experiments, the efficiency of blocking was unchanged and remained at $50 \%$ of the control levels (data not shown). These data suggest that binding of an L1CAM-blocking antibody impedes subsequent binding or the function of the other blocking antibody.

TGF- $\beta$ and integrin $\beta 3$ expression influences cell survival and tumor growth in a mouse model of orthotopic lung cancer

To validate our in vitro findings in an in vivo setting, we developed an orthotopic model of lung cancer by directly injecting integrin $\beta 3$-deficient or integrin $\beta 3$-competent H157 cells into the lungs of immune-deficient mice, with or without TGF- $\beta$ pretreatment. To study the importance of stromal-derived TGF- $\beta$, mice received daily intraperitoneal injections of the TGF- $\beta$ inhibitor peptide P144 $(200 \mu \mathrm{g})$, and survival was analyzed by Kaplan-Meier curves (Figure 5A). No significant differences in survival were observed between mice injected with $\mathrm{H} 157$ cells previously exposed to TGF- $\beta$ or not. By contrast, the survival of mice injected with $\beta 3$ integrin-silenced tumor cells was significantly higher, increasing from $30 \%$ to $80 \%$ that of the controls. In some cases mice injected with cells transfected with commercial nonspecific shRNA showed mixed responses, even though these cells were successfully used in vitro. Indeed, further analysis of this RNA sequence revealed some similarity $(60 \%)$ with the RNA sequences of bone morphogenic protein 2 (BMP2) and SMAD5, both of which are involved in TGF- $\beta$ signaling, which may explain the source of these spurious results. Inhibiting stromal TGF- $\beta$ by intraperitoneal administration of P144 increased the survival rates in all groups regardless of whether the cells injected were untreated or pretreated with TGF- $\beta$. 


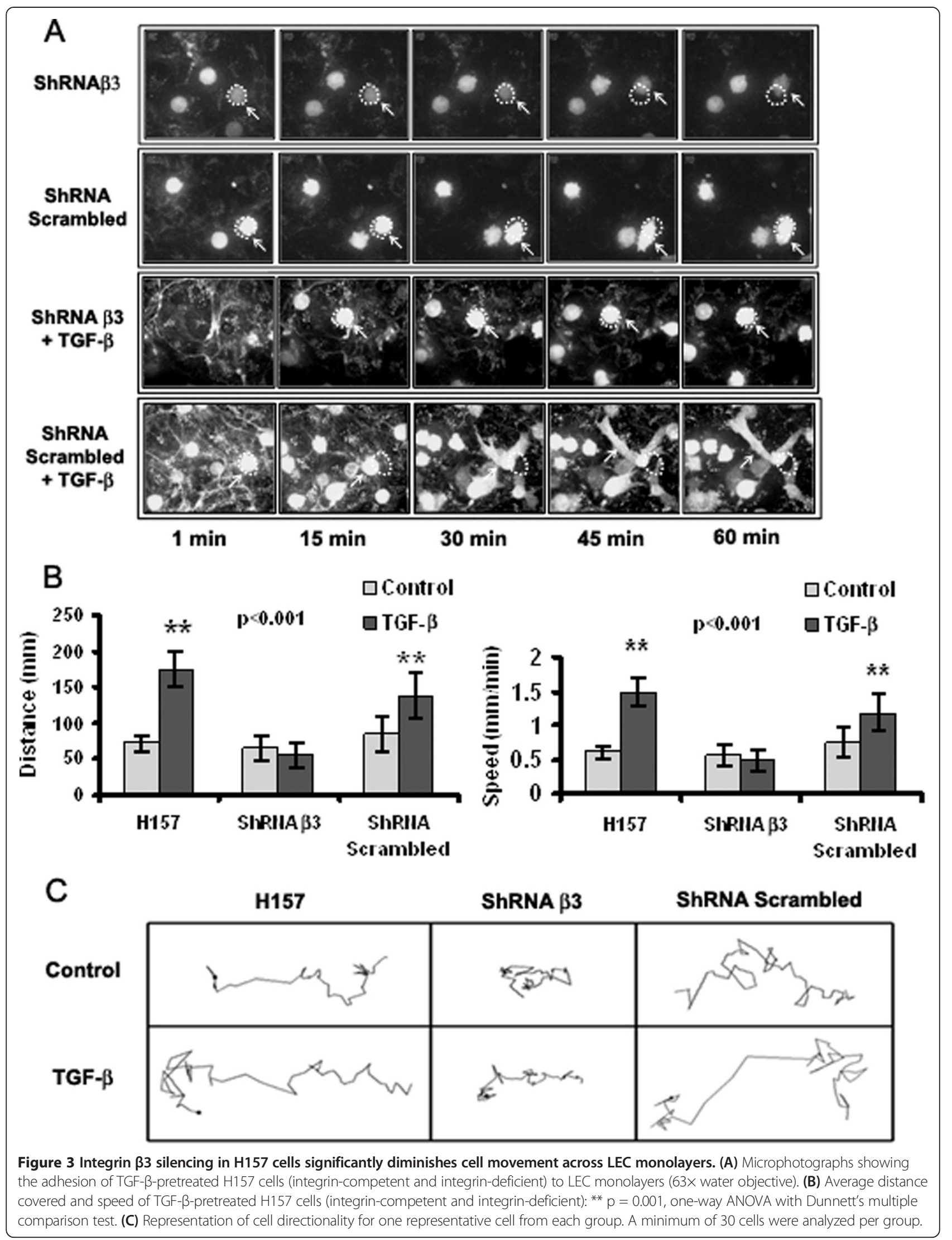




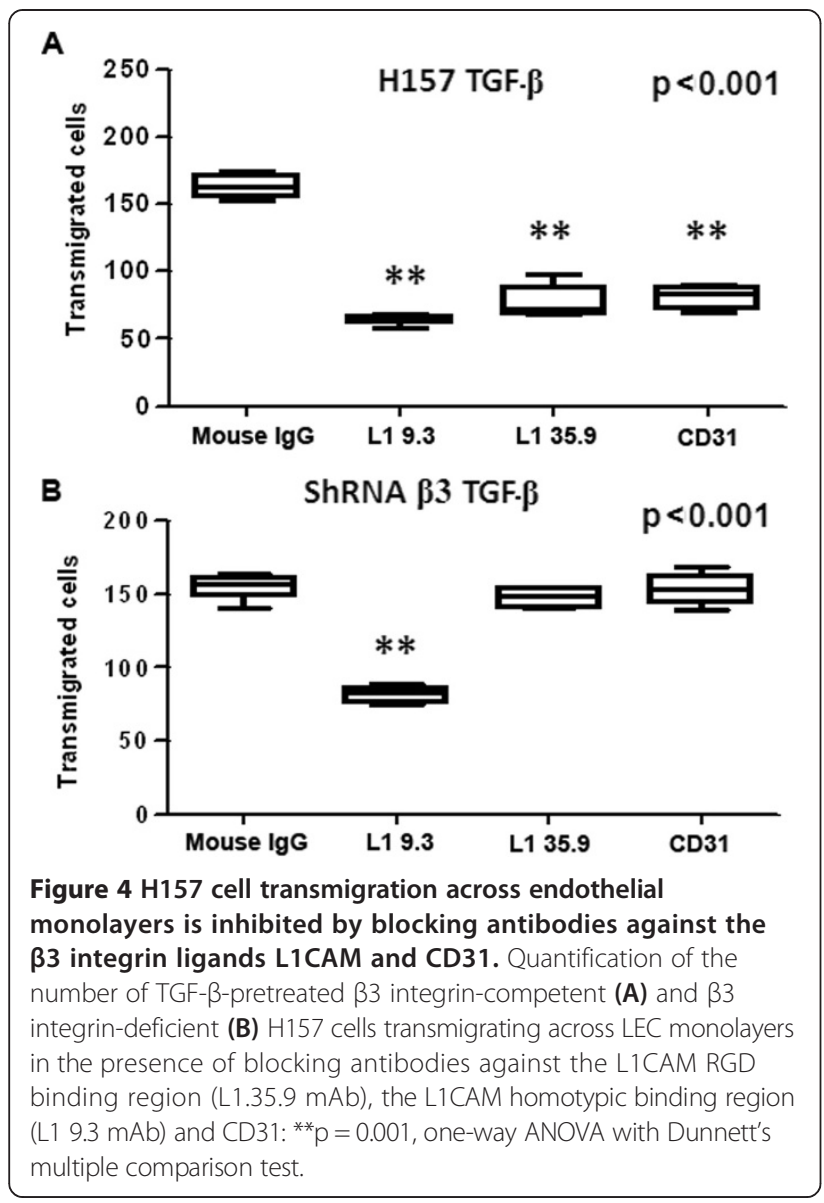

Tumor histology was analyzed after sacrificing the mice, revealing that $\mathrm{H} 157$ tumor cells pretreated with TGF- $\beta$ formed larger tumors than untreated cells. Moreover, this growth was abrogated when mice were treated with the inhibitory peptide P144 (Figure 5B), while the smallest tumors were detected in animals injected with integrin $\beta 3$-silenced cells $\left(\right.$ mean size $\left.=0.06 \mathrm{~cm}^{2}\right)$. These findings were supported by the results of micro-CT analyses of mice prior to sacrificing. In mice injected with integrin $\beta 3$-silenced cells and treated with the TGF- $\beta$ inhibitor peptide P144, tumor affected lung area was smaller than that observed in control samples (Figure 5C). Hence, the inhibition of cell adhesion through integrin silencing and/ or the inhibition of stromal TGF- $\beta$ limit tumor growth and favors survival in our experimental model.

\section{Concomitant TGF- $\beta 1$ inhibition and integrin $\beta 3$ silencing decreases lymph node metastasis in mice}

Since our in vitro results suggested the participation of $\beta 3$ integrin in H157 cell transmigration across LECs, we quantified the percentage of lymph nodes affected by tumor cells in each of the experimental groups (Figure 6). TGF- $\beta$ pretreatment of $\mathrm{H} 157$ cells had no effect on their ability to form metastatic foci in lymph nodes. In contrast, in mice injected with untreated cells, the inhibition of stromal TGF- $\beta$ by intraperitoneal injection of P144 resulted in an important diminution of the incidence of metastasis to the lymph nodes from $80 \%$ to $21 \%(\mathrm{p}=0.009)$ with respect to control animals. Furthermore, mice injected with $\mathrm{H} 157$ cells in which $\beta 3$ integrin had been silenced displayed less lymph node affectation than those injected with $\beta 3$ integrin-competent cells $(57 \%$ vs. $80 \%)(\mathrm{p}=0.24)$.

We observed significant variation in the results when mice were injected with $\mathrm{H} 157$ cells that had been pretreated with TGF- $\beta$ in vitro. In this case, lymph node affectation did not differ between mice that received $\beta 3$ integrin-competent and $\beta 3$ integrin-deficient cells, with rates of $\sim 80 \%$ observed in both groups of mice. This suggests that a compensatory mechanism is triggered in H157 cells after TGF- $\beta$ exposure that enables them to overcome the lack of $\beta 3$ integrin and promote cell migration towards the lymph nodes. The inhibition of stromal TGF- $\beta$ by intraperitoneal injection of P144 also failed to prevent metastasis to the lymph nodes in mice injected with $\beta 3$ integrin-competent $\mathrm{H} 157$ cells that were pretreated with TGF- $\beta$. Thus, TGF- $\beta$ pretreatment allowed tumors to overcome the specific silencing of integrin $\beta 3$ expression or the inhibition of TGF- $\beta$ in the tumor stroma. Importantly, when we injected $\beta 3$ integrindeficient $\mathrm{H} 157$ cells that had been pretreated with TGF- $\beta$ in mice that were subsequently treated with P144, the incidence of lymph node affectation dropped from $80 \%$ to $42 \%(\mathrm{p}=0.009)$. These findings indicate that concurrent targeting of integrin $\beta 3$ and TGF- $\beta$ signaling significantly attenuates the incidence of lymph node metastases in cells that have evolved towards more aggressive phenotypes due to TGF- $\beta$ exposure.

\section{Discussion}

The induction of angiogenesis, invasion and metastasis by TGF- $\beta$ in advanced stages of cancer has been well demonstrated [29]. Accordingly, the inhibition of TGF$\beta$-mediated signaling has aroused great interest in the scientific community as a potential therapeutic approach to cancer treatment. Small molecule inhibitors such as the TGF- $\beta$ RI inhibitors LY2157299, SB-50124 and SM16, monoclonal antibodies such as lerdelimumab, metelimumab, fresolimumab and IMC-TR1, and anti-sense mRNA molecules such as trabedersen and lucanix have yielded promising results in preclinical research and clinical trials. However, none of these compounds have yet been approved for clinical use due to the severe side effects observed in some patients, including cardiac toxicity, gastro-intestinal symptoms, fatigue, skin rash and epistaxis [33].

While much has been written on the role of TGF- $\beta$ in metastasis, there is little information on the mechanisms 


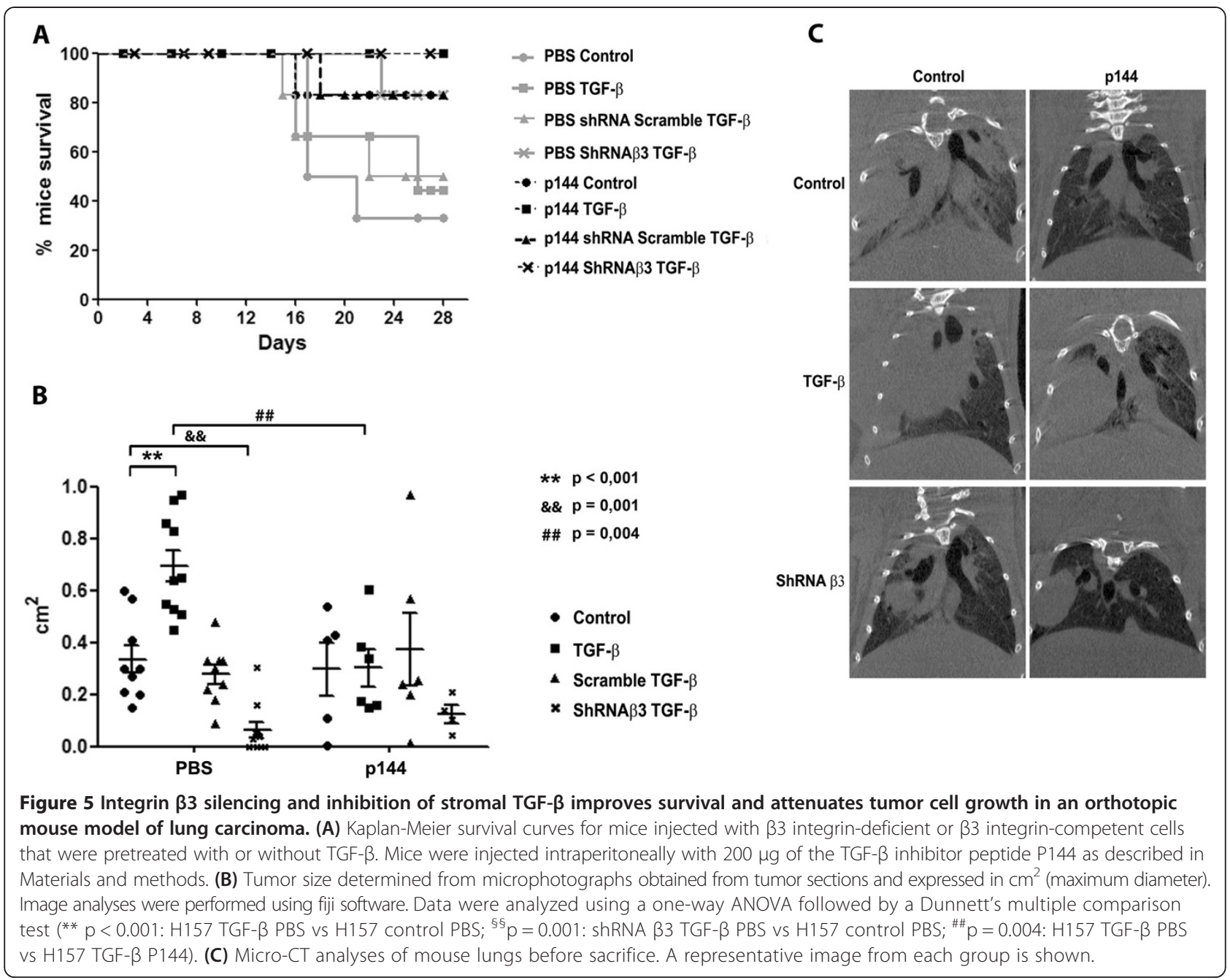

that govern the movement of tumor cells from tissues into the lymphatic flow and towards the lymph nodes. We demonstrate that TGF- $\beta$ pretreatment increases the chemotaxis, adhesion and transmigration of $\mathrm{H} 157$ cells, a cell line derived from squamous cell lung carcinoma, across monolayers of primary lymphatic endothelial cells of the lung. This dynamic change is accompanied by an increase in the expression of metastasis-related genes and a switch from amoeboid to mesenchymal-like cellular movement. Mesenchymal cell movement has been associated with the formation of focal adhesion contacts, a process in which integrins play a prominent role [34].

TGF- $\beta$ triggers a complex network of signaling cascades that appear to involve cross-talk between integrins and TGF- $\beta$ [35]. We observed an increase in the expression of several integrins at both the mRNA and protein levels that was particularly notable in the case of $\beta 3$ integrin. This observation is consistent with previous reports describing TGF- $\beta$-induced increments in $\beta 3$ integrin mRNA and protein expression, and $\alpha v \beta 3$ surface expression in human lung fibroblasts via a $\beta 3$ integrin, c-Src- and p38 MAPK-dependent pathway [36].

The expression of $\alpha \mathrm{v} \beta 3$ integrin in tumor cells has been associated with poor prognosis and increased metastasis in several carcinoma types, including osteosarcoma, pancreas and breast cancers [37-39]. In the present study, we observed decreased tumor cell adhesion and transmigration across monolayers of lymphatic endothelial cells when $\beta 3$ integrin was blocked or silenced in tumor cells. Blockade of the $\beta 3$ integrin ligands L1CAM and CD31 reduced tumor cell transmigration, supporting the role of active adhesion mechanisms in tumor cell transit across lymphatic endothelial cells in our experimental conditions. Indeed, previous works described binding of $\alpha v \beta 3$ integrin as expressed by melanoma cells to blood vascular endothelium via endothelium-expressed L1CAM [40,41]. Furthermore, hypoxia has been show to induce L1CAM-mediated breast cancer cell adhesion to tumor microvasculature [42].

The role of $\beta 3$ integrin in metastasis is not restricted to cell adhesion and it is also involved in the regulation 


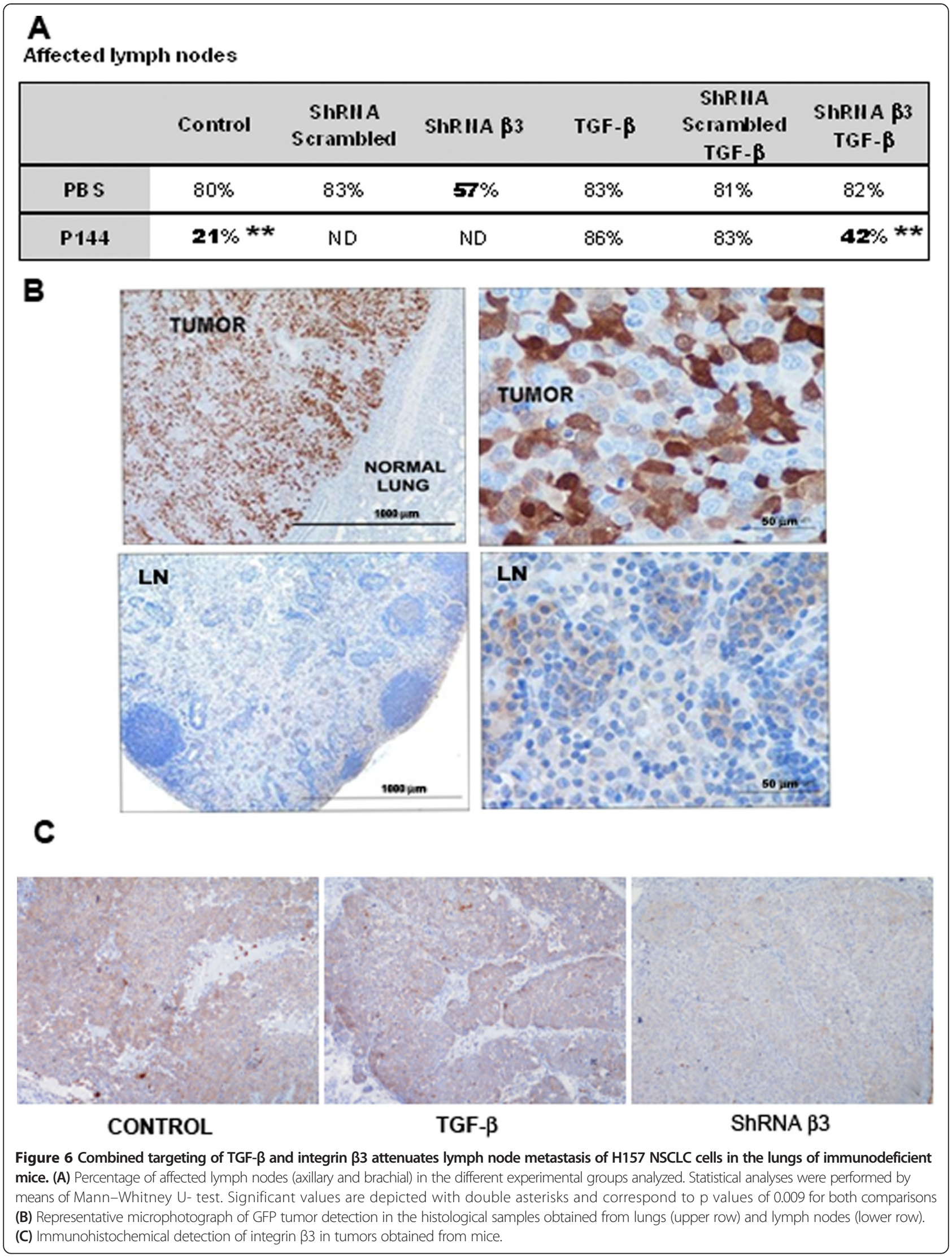


of TGF- $\beta$ bioavailability. In fact, the TGF- $\beta$-mediated induction of $\beta 3$ integrin has been described as part of a positive feed-back loop in which $\beta 3$ integrin facilitates TGF- $\beta$ activation [43] by binding to the RGD domains in the complexes formed between TGF- $\beta$ and the Latent Associated Peptide (LAP). This activation contributes to TGF- $\beta$-stimulated cancer metastasis in mammary epithelial cells [43]. The active cross-talk between TGF- $\beta$ and integrins is triggered in tumors in response to hypoxia, oxidative stress or therapy, and it promotes tumor survival. For example, radiotherapy increases $\alpha v \beta 3$ integrin expression as a survival mechanism in NSCLC H157 and H460 cell lines and consequently tumor growth is reduced by a combination of radiotherapy and treatment with the $\beta 3$ integrin antagonist Cilengitide [44]. We observed increased survival and decreased tumor size in mice injected with $\beta 3$ integrin-deficient cells as compared with those injected with $\beta 3$ integrin-competent cells. Moreover, the effects of the TGF- $\beta$ inhibitory peptide P144, which significantly enhances survival and attenuates tumor growth, were more dramatic in mice injected with $\beta 3$-integrin-deficient cells. Treatment with P144 has been shown to inhibit tumor growth [45], angiogenesis [46] and metastasis [47], and to potentiate the efficacy of anti-tumor immunotherapy [48] in several animal tumor models.

When we analyzed lymph node affectation, we found that the inhibition of stromal TGF- $\beta$ with P144 greatly diminished the appearance of tumor cells in the lymph nodes of animals injected with untreated H157 cells. These results are consistent with previous findings highlighting the role of stromal-produced TGF- $\beta$ in the establishment of metastasis from primary tumors [49]. Remarkably, silencing of $\beta 3$ integrin in the same tumors also reduced tumor cell transit to the lymph nodes to half the levels observed in mice injected with $\beta 3$ integrin-competent cells.

Surprisingly, in vitro pretreatment of cells with TGF- $\beta$ did not increase further metastasis to the lymph nodes of H157 NSCLC cells in comparison with the already high basal metastatic counts $(80 \%)$ due perhaps to an excessively long end point for these experiments. In addition, TGF- $\beta$-pretreated tumor cells were resistant to separate targeting of $\beta 3$ integrin silencing or stromal TGF- $\beta$ inhibition with P144. This resistance may be explained by the acquisition incremented competences to bind and activate TGF- $\beta$ exemplified by the increased expression of other integrins, such as $\alpha v \beta 5$ and $\alpha 4 \beta 1$, and extracellular matrix degrading proteases such as MMPs.

Therefore, although the interplay between integrin $\beta 3$ and TGF- $\beta$ and between tumor and stromal cells in these animals remains to be fully elucidated, it is suggesting the fact that the phenotype of TGF- $\beta 1^{-1-}$ mice is fully reproduced in mice with mutations in the RGD binding motif in the amino acidic sequence of LAP [50]. Given the role of integrin $\beta 3$ in TGF- $\beta$-mediated proteolytic activation (33) and the binding of P144 to TGF- $\beta$, we propose that these two molecules are in competition for TGF- $\beta$ binding. Thus, when integrin $\beta 3$ expression is low (control cells), P144 can bind more efficiently to TGF- $\beta$ and exert its inhibitory activity. However, after TGF- $\beta$ exposure incremented numbers of integrin $\beta 3$ molecules expressed on the cell membrane bind to and activate TGF- $\beta$, thereby competing P144 binding to its target. In keeping with this hypothesis, mice injected with tumor cells that were pretreated with TGF- $\beta$ but in which integrin $\beta 3$ expression was silenced responded to P144 treatment with significantly impaired metastasis to the lymph nodes. These findings suggest that TGF- $\beta$ pretreated cells are primed for subsequent activation by stromal TGF- $\beta$ to increase their metastatic potential.

This is not the first time combined treatments that include TGF- $\beta$ inhibitors have been proposed. Indeed, several studies have demonstrated that the administration of TGF- $\beta$ inhibitors in combination with immune-stimulating vaccines or cytotoxic agents improve the efficacy of current TGF- $\beta$-based therapies [51]. However, in the case of integrin inhibiting peptides, caution is advised as for example, the inhibition of $\beta 1$ integrin in models of mammary carcinoma activates the expression the $\beta 3$ integrin and TGF- $\beta$ mediated metastasis [52]. Accordingly, the correct integrin/TGF- $\beta$ interaction must be identified before embarking upon complex therapeutic approaches.

\section{Conclusions}

In this work we provide preclinical data to support the combined targeting of TGF- $\beta$ and $\beta 3$ integrin as a promising therapeutic approach to attenuate lung cancer metastasis to the lymph nodes in those tumors that are refractory to TGF- $\beta$ directed monotherapy.

\section{Additional files}

\section{Supplementary experimental procedures}

Western blots - Primary antibodies against TGF- $\beta 1$ (1:300) and TGF- $\beta R I I$ (1:600) were purchased from R\&D Systems (Minneapolis, USA), while anti-p-Smad2 (1:2000) was obtained from Chemicon and anti-Smad 2/3 (1:2000) from Cell Signaling.

Migration, chemotaxis and flow cytometry were performed as described previously (23).

\footnotetext{
Additional file 1: Figure S1. NSCLC cell lines respond to TGF- $\beta$-mediated signaling. (A) Induction of Smad2 phosphorylation 30 min after pretreatment with TGF- $\beta$ in the NSCLC cell lines A549, H157 and H1299, both in the presence or absence of the TGF- $\beta$ inhibitor P144 (20 or $200 \mathrm{ng} / \mathrm{ml}$ ) and SB431542 for H157 cells. (B) Chemotaxis of TGF- $\beta$-treated NSCLC cells in fibronectin $(10 \mathrm{pg} / \mathrm{ml})$ or vitronectin $(1 \mu \mathrm{g} / \mathrm{ml})$ coated Boyden chambers (** $p<0.001$, Mann-Whitney U-test). (C) TGF- $\beta$-induced cell migration towards the chemotactic cytokines CXCL12, CCL21 and MIP1a (**p $<0.001$, Mann-Whitney U-test).
} 
Additional file 2: Figure S2. Fold changes in the expression of genes related to cell migration after TGF- $\beta$ exposure of H157 NSCLC cells. (A) Fold values obtained from SABiosciences $\mathrm{RT}^{2}$ Profilerm $^{\mathrm{TM}} \mathrm{PCR}$ Array from those genes that presented differential expression. (B) Confirmation by Real-Time PCR analyses of the differential expression of some genes in experiments performed independently.

Additional file 3: Figure S3. Surface expression of L1CAM and CD31 on H157 cells and LECs. Flow cytometry analysis of L1CAM and CD31cell surface expression on LECS (A) and H157 cells (B) with or without prior exposure to TGF- $\beta$. LECs were also incubated with TNFa as a control. The fold-change with respect to untreated cells is indicated in the figure.

\section{Competing interests}

The authors do not have any financial competing interest to disclosure.

\section{Authors' contributions}

ES: performed de in vitro experiments, treated animals, extracted data and analyzed it. SG: performed the animal experiments, histologies and video recording of the cells. JD, helped to set up the animal model and supported all the experimentation performed with P144 inhibitory peptide. XM, helped with statistics and confocal imaging. RP, contributed to all the in vitro analysis of cell migration and adhesion to different substrates. PA designed and supervised all the experiments in which anti L1-CAM antibodies were used. AR: design the project and experimental approach, supervised all the results and wrote the manuscript. All authors read and approved the final manuscript.

\section{Acknowledgements}

This work was supported by the Spanish Ministry of Health Grant PI10/02131 (Institute Carlos III) and by a Grant from the Foundation for Applied Medical Research (FIMA), Spain. We thank Dr Mark Sefton from BiomedRed who provided medical writing services.

\section{Author details}

'Oncology, CIMA, 31008 Pamplona, Spain. ${ }^{2}$ DIGNA-Biotech, 31008 Pamplona, Spain. ${ }^{3}$ Department of Translational Immunology, German Cancer Research Center, D015, Heidelberg D 69120, Germany. ${ }^{4}$ Department of Biochemistry and Genetics, University of Navarra, 31080 Pamplona, Spain.

Received: 3 January 2014 Accepted: 9 May 2014

Published: 19 May 2014

\section{References}

1. Siegel R, Naishadham D, Jemal A: Cancer statistics, 2013. CA Cancer J Clin 2013, 63(1):11-30

2. Milara J, Peiró T, Serrano A, Cortijo J: Epithelial to mesenchymal transition is increased in patients with COPD and induced by cigarette smoke. Thorax 2013, 68(5):410-420.

3. Malkoski S, Haeger S, Cleaver T, Rodriguez K, Li H, Lu S, Feser W, Barón A Merrick D, Lighthall J, ljichi H, Franklin W, Wang X: Loss of transforming growth factor beta type II receptor increases aggressive tumor behavior and reduces survival in lung adenocarcinoma and squamous cell carcinoma. Clin Cancer Res 2012, 18(8):2173-2183.

4. Tian M, Neil J, Schiemann W: Transforming growth factor- $B$ and the hallmarks of cancer. Cell Signal 2011, 23(6):951-962.

5. Zamarron B, Chen W: Dual roles of immune cells and their factors in cancer development and progression. Int J Biol Sci 2011, 7(5):651-658.

6. Du S, Barcellos-Hoff MH: Tumors as organs: biologically augmenting radiation therapy by inhibiting transforming growth factor $\beta$ activity in carcinomas. Semin Radiat Oncol 2013, 23(4):242-251.

7. Bhola NE, Balko JM, Dugger TC, Kuba MG, Sánchez V, Sanders M, Stanford J, Cook RS, Arteaga CL: TGF- $\beta$ inhibition enhances chemotherapy action against triple-negative breast cancer. J Clin Invest 2013, 123(3):1348-1358

8. Kawai H, Minamiya Y, Ito M, Saito H, Ogawa J: VEGF121 promotes lymphangiogenesis in the sentinel lymph nodes of non-small cell lung carcinoma patients. Lung Cancer 2008, 59(1):41-47.

9. Wang J, Guo Y, Wang B, Bi J, Li K, Liang X, Chu H, Jiang H: Lymphatic microvessel density and vascular endothelial growth factor- $C$ and $-D$ as prognostic factors in breast cancer: a systematic review and metaanalysis of the literature. Mol Biol Rep 2012, 39(12):11153-11165.
10. Yamashita T, Uramoto H, Onitsuka T, Ono K, Baba T, So T, Takenoyama M, Hanagiri T, Oyama T, Yasumoto K: Association between lymphangiogenesis-/ micrometastasis- and adhesion-related molecules in resected stage I NSCLC. Lung Cancer 2010, 70(3):320-328.

11. Zigrino $P$, Löffek $S$, Mauch C: Tumor-stroma interactions: their role in the control of tumor cell invasion. Biochimie 2005, 87(3-4):321-328.

12. Irigoyen M, Pajares M, Agorreta J, Ponz-Sarvisé M, Salvo E, Lozano M, Pío R, Gil Bazo I, Rouzaut A: TGFBI expression is associated with a better response to chemotherapy in NSCLC. Mol Cancer 2010, 9:130-130.

13. Azzali G: The modality of transendothelial passage of lymphocytes and tumor cells in the absorbing lymphatic vessel. Eur J Histochem 2007, 51(Suppl 1):73-77.

14. Pflicke $H$, Sixt M: Preformed portals facilitate dendritic cell entry into afferent lymphatic vessels. J Exp Med 2009, 206(13):2925-2935.

15. Saharinen P, Tammela T, Karkkainen MJ, Alitalo K: Lymphatic vasculature: development, molecular regulation and role in tumor metastasis and inflammation. Trends Immunol 2004, 25(7):387-395.

16. Lämmermann T, Bader BL, Monkley SJ, Worbs T, Wedlich-Söldner R, Hirsch K, Keller M, Förster R, Critchley DR, Fässler R, Sixt M: Rapid leukocyte migration by integrin-independent flowing and squeezing. Nature 2008, 453(7191):51-55.

17. Yao LC, Baluk P, Srinivasan RS, Oliver G, McDonald DM: Plasticity of button-like junctions in the endothelium of airway lymphatics in development and inflammation. Am J Pathol 2012, 180(6):2561-2575.

18. Johnson LA, Jackson DG: Inflammation-induced secretion of CCL21 in lymphatic endothelium is a key regulator of integrin-mediated dendritic cell transmigration. Int Immunol 2010, 22(10):839-849.

19. Rouzaut A, Garasa S, Teijeira Á, González I, Martinez-Forero I, Suarez N, Larrea E, Alfaro C, Palazón A, Dubrot J, Hervás-Stubbs S, Melero I: Dendritic cells adhere to and transmigrate across lymphatic endothelium in response to IFN-a. Eur J Immunol 2010, 40(11):3054-3063.

20. Galon J, Angell HK, Bedognetti D, Marincola FM: The continuum of cancer immunosurveillance: prognostic, predictive, and mechanistic signatures. Immunity 2013, 39(1):11-26.

21. Kawashima A, Tsugawa S, Boku A, Kobayashi M, Minamoto T, Nakanishi I, Oda $Y$ : Expression of av integrin family in gastric carcinomas: increased av $\beta 6$ is associated with lymph node metastasis. Pathol Res Pract 2003, 199(2):57-64.

22. Li F, Liu Y, Kan X, Li Y, Liu M, Lu JG: Elevated expression of integrin av and $\beta 5$ subunit in laryngeal squamous-cell carcinoma associated with lymphatic metastasis and angiogenesis. Pathol Res Pract 2013, 209(2):105-109.

23. Irigoyen M, Ansó E, Martínez E, Garayoa M, Martínez Irujo JJ, Rouzaut A: Hypoxia alters the adhesive properties of lymphatic endothelial cells. A transcriptional and functional study. Biochim Biophys Acta 2007, 1773(6):880-890.

24. Martínez-García E, Irigoyen M, González-Moreno Ó, Corrales L, Teijeira Á, Salvo E, Rouzaut A: Repetitive nicotine exposure leads to a more malignant and metastasis-prone phenotype of SCLC: a molecular insight into the importance of quitting smoking during treatment. Toxicol $\mathrm{Sci}$ 2010, 116(2):467-476.

25. Wolterink S, Moldenhauer G, Fogel M, Kiefel H, Pfeifer M, Lüttgau S, Gouveia R, Costa J, Endell J, Moebius U, Altevogt P: Therapeutic antibodies to human L1CAM: functional characterization and application in a mouse model for ovarian carcinoma. Cancer Res 2010, 70(6):2504-2515.

26. Doki Y, Murakami K, Yamaura T, Sugiyama S, Misaki T, Saiki I: Mediastinal lymph node metastasis model by orthotopic intrapulmonary implantation of Lewis lung carcinoma cells in mice. Br J Cancer 1999, 79(7-8):1121-1126.

27. Muñoz-Barrutia A, Ceresa M, Artaechevarria X, Montuenga LM, Ortiz-de-Solorzano C: Quantification of lung damage in an elastase-induced mouse model of emphysema. Int J Biomed Imag 2012, 2012:734734-734734.

28. Friedl $\mathrm{P}$, Wolf K: Plasticity of cell migration: a multiscale tuning model. J Cell Biol 2010, 188(1):11-19.

29. Padua D, Massague J: Roles of TGFbeta in metastasis. Cell Res 2009, 19(1):89-102.

30. Ezquerro I, Lasarte J, Dotor J, Castilla-Cortázar I, Bustos M, Peñuelas I, Blanco G, Rodríguez C, Lechuga MCG, Greenwel P, Rojkind M, Prieto J, Borrás-Cuesta F: A synthetic peptide from transforming growth factor beta type III receptor inhibits liver fibrogenesis in rats with carbon tetrachloride liver injury. Cytokine 2003, 22(1-2):12-20.

31. Schäfer H, Dieckmann C, Korniienko O, Moldenhauer G, Kiefel H, Salnikov A, Krüger A, Altevogt P, Sebens S: Combined treatment of L1CAM antibodies 
and cytostatic drugs improve the therapeutic response of pancreatic and ovarian carcinoma. Cancer Lett 2012, 319(1):66-82

32. Weinspach $D$, Seubert $B$, Schaten $S$, Honert $K$, Sebens $S$, Altevogt $P$, Krüger A: Role of L1 cell adhesion molecule (L1CAM) in the metastatic cascade: promotion of dissemination, colonization, and metastatic growth. Clin Exp Metastasis 2014, 31(1):87-100.

33. Connolly E, Freimuth J, Akhurst R: Complexities of TGF- $\beta$ targeted cancer therapy. Int J Biol Sci 2012, 8(7):964-978,

34. Friedl $P$, Wolf $K$ : Tumour-cell invasion and migration: diversity and escape mechanisms. Nat Rev Cancer 2003, 3(5):362-374.

35. Mamuya FA, Duncan MK: aV integrins and TGF- $\beta$-induced EMT: a circle of regulation. J Cell Mol Med 2012, 16(3):445-455.

36. Pechkovsky DV, Scaffidi AK, Hackett TL, Ballard J, Shaheen F, Thompson PJ, Thannickal VJ, Knight DA: Transforming growth factor beta1 induces alphavbeta3 integrin expression in human lung fibroblasts via a beta3 integrin-, c-Src-, and p38 MAPK-dependent pathway. J Biol Chem 2008, 283(19):12898-12908.

37. Marchán S, Pérez-Torras S, Vidal A, Adan J, Mitjans F, Carbó N, Mazo A: Dual effects of $\beta 3$ integrin subunit expression on human pancreatic cancer models. Anal Cell Pathol 2010, 33(5):191-205.

38. Takayama S, Ishii S, Ikeda T, Masamura S, Doi M, Kitajima M: The relationship between bone metastasis from human breast cancer and integrin alpha(v)beta3 expression. Anticancer Res 2005, 25(1A):79-83.

39. Tome $Y$, Kimura H, Maehara H, Sugimoto N, Bouvet M, Tsuchiya H, Kanaya F, Hoffman RM: High lung-metastatic variant of human osteosarcoma cells, selected by passage of lung metastasis in nude mice, is associated with increased expression of a(v) $\beta(3)$ integrin. Anticancer Res 2013, 33(9):3623-3627.

40. Voura EB, Ramjeesingh RA, Montgomery AM, Siu CH: Involvement of integrin alpha(v)beta(3) and cell adhesion molecule L1 in transendothelial migration of melanoma cells. Mol Biol Cell 2001, 12(9):2699-2710

41. Issa Y, Nummer D, Seibel T, Müerköster S, Koch M, Schmitz Winnenthal F, Galindo L, Weitz J, Beckhove P, Altevogt P: Enhanced L1CAM expression on pancreatic tumor endothelium mediates selective tumor cell transmigration. J Mol Med 2009, 87(1):99-112.

42. Zhang $\mathrm{H}$, Wong CC, Wei H, Gilkes DM, Korangath P, Chaturvedi P, Schito L, Chen J, Krishnamachary B, Winnard PT Jr, Raman V, Zhen L, Mitzner WA, Sukumar S, Semenza GL: HIF-1-dependent expression of angiopoietin-like 4 and L1CAM mediates vascular metastasis of hypoxic breast cancer cells to the lungs. Oncogene 2012, 31(14):1757-1770.

43. Worthington JJ, Klementowicz JE, Travis MA: TGF $\beta$ : a sleeping giant awoken by integrins. Trends Biochem Sci 2011, 36(1):47-54

44. Albert J, Cao C, Geng L, Leavitt L, Hallahan D, Lu B: Integrin alpha v beta 3 antagonist Cilengitide enhances efficacy of radiotherapy in endothelial cell and non-small-cell lung cancer models. Int J Radiat Oncol Biol Phys 2006, 65(5):1536-1543.

45. Díaz-Valdés N, Basagoiti M, Dotor J, Aranda F, Monreal I, Riezu Boj J, Borrés-Cuesta F, Sarobe P, Feijoó E: Induction of monocyte chemoattractant protein-1 and interleukin-10 by TGFbeta 1 in melanoma enhances tumor infiltration and immunosuppression. Cancer Res 2011, 71(3):812-821.

46. Serratì S, Margheri F, Pucci M, Cantelmo AR, Cammarota R, Dotor J, Borràs-Cuesta F, Fibbi G, Albini A, Del Rosso M: TGFbeta1 antagonistic peptides inhibit TGFbeta1-dependent angiogenesis. Biochem Pharmacol 2009, 77(5):813-825.

47. Zubeldia IG, Bleau AM, Redrado M, Serrano D, Agliano A, Gil-Puig C, Vidal-Vanaclocha F, Lecanda J, Calvo A: Epithelial to mesenchymal transition and cancer stem cell phenotypes leading to liver metastasis are abrogated by the novel TGF $\beta 1$-targeting peptides P17 and P144. Exp Cell Res 2013, 319(3):12-22.

48. Llopiz D, Dotor J, Casares N, Bezunartea J, Díaz-Valdés N, Ruiz M, Aranda F, Berraondo P, Prieto J, Lasarte J, Borrás-Cuesta F, Sarobe P: Peptide inhibitors of transforming growth factor-beta enhance the efficacy of antitumor immunotherapy. Int J Cancer 2009, 125(11):2614-2623.

49. Connolly EC, Freimuth J, Akhurst RJ: Complexities of TGF- $\beta$ targeted cancer therapy. Int J Biol Sci 2012, 8(7):964-978.

50. Yang Z, Mu Z, Dabovic B, Jurukovski V, Yu D, Sung J, Xiong X, Munger JS: Absence of integrin-mediated TGFbeta1 activation in vivo recapitulates the phenotype of TGFbeta1-null mice. J Cell Biol 2007, 176(6):787-793.
51. Perrot $C Y$, Javelaud D, Mauviel A: Overlapping activities of TGF- $\beta$ and Hedgehog signaling in cancer: therapeutic targets for cancer treatment. Pharmacol Ther 2013, 137(2):183-199.

52. Parvani JG, Galliher-Beckley AJ, Schiemann BJ, Schiemann WP: Targeted inactivation of $\beta 1$ integrin induces $\beta 3$ integrin switching that drives breast cancer metastasis by TGF- $\beta$. Mol Biol Cell 2013, 24(21):3449-3459.

doi:10.1186/1476-4598-13-112

Cite this article as: Salvo et al:: Combined targeting of TGF- $\beta 1$ and integrin $\beta 3$ impairs lymph node metastasis in a mouse model of non-small-cell lung cancer. Molecular Cancer 2014 13:112.

\section{Submit your next manuscript to BioMed Central and take full advantage of:}

- Convenient online submission

- Thorough peer review

- No space constraints or color figure charges

- Immediate publication on acceptance

- Inclusion in PubMed, CAS, Scopus and Google Scholar

- Research which is freely available for redistribution 